\title{
Effects of Whey Protein Isolate Ingestion on Muscle Protein Synthesis at Rest and After Resistance-exercise in Middle-aged Men: A Research Protocol
}

\author{
David Zhao*, BSc Student [1], Parrish Evers, BSc Student [2] \\ All authors contributed equally.
}

[1] Department of Biomedical and Molecular Sciences, Queen's University, Kingston, Ontario, Canada, K7L 3N6

[2] Department of Chemistry and Biomolecular Sciences, University of Ottawa, Ottawa, Ontario, Canada, K1N 6N5

*Corresponding Author: $17 \mathrm{dmez@queensu.ca}$

\begin{abstract}
Introduction: Sarcopenia is a syndrome primarily found in elderly individuals and is defined by decreased skeletal muscle mass and strength. Sarcopenia often increases the risk or is comorbid with various diseases. Thus, the objective of this study is to determine the appropriate dosage of whey protein isolate (WPI) for middle-aged men at rest and after resistance-exercise for maximum muscle protein synthesis (MPS) and to reduce the risk of sarcopenia.

Methods: 50 healthy men (age $45 \pm 5 \mathrm{yrs}$, BMI $<30 \mathrm{~kg} / \mathrm{m}^{2}$ ) will be randomly assigned an amount of ingested WPI $(0 \mathrm{~g}, 10 \mathrm{~g}, 20 \mathrm{~g}, 30 \mathrm{~g}, 40 \mathrm{~g}) .24$ hours prior, a baseline saliva sample and ingestion of 5 doses of $150 \mathrm{~mL}$ bolus $\left(70 \% \mathrm{D}_{2} \mathrm{O}\right)$ every 2 hours will be completed at the participants' own homes. On the day of the study, a saliva sample will be taken 1 hour before 10 repetitions of maximum unilateral leg extension. After the exercise protocol $(\mathrm{t}=0 \mathrm{~h})$, saliva samples will be obtained every hour until $\mathrm{t}=6 \mathrm{~h}$ and 3 muscle biopsies at $\mathrm{t}=0 \mathrm{~h}, \mathrm{t}=3 \mathrm{~h}$, and $\mathrm{t}=6 \mathrm{~h}$. After isolating myofibrillar protein fractions from the biopsies, the samples will be analyzed using gas chromatography-pyrolysis-isotope ratio mass spectrometer (GC-P-IRMS). Analysing saliva samples will be conducted using temperature conversion elemental analyzer (TC/EA) followed by isotope ratio mass spectrometer (IRMS). Atom percent excess for both deuterium enrichment of protein-bound alanine and precursor enrichment will be conducted to allow the calculation of fractional synthetic rate (FSR, \%/h).

Discussion: We anticipate FSR $(\% / \mathrm{h})$ will be significantly greater in the exercised leg compared to the unexercised leg at each WPI ingestion dosage. Furthermore, we anticipate that $\geq 20 \mathrm{~g}$ of ingested WPI will be sufficient for maximal MPS at rest. Finally, we anticipate that at $\geq 30 \mathrm{~g}$ ingestion of WPI will be sufficient for maximal MPS after resistance training. It is beneficial for physicians to know the optimal dose for MPS in middle-aged adults, so they can suggest more accurate recommendations of proactive protein intake. This will help alleviate the high prevalence of sarcopenia and its detrimental effects on health, healthcare, and the economy.
\end{abstract}

Keywords: sarcopenia; middle-aged men; myofibrillar protein synthesis; whey protein isolate; muscle anabolism; deuterium oxide; fractional synthetic rate; resistance exercise

\section{Introduction}

Broadly speaking, sarcopenia is a syndrome marked by decreased muscle mass and decreased strength [1,2]. Sarcopenia is frequent in individuals aged 65 and above $[1,3]$ and much of the current research assesses its presence in older individuals. Some studies have compared findings in younger adults in their 20s with these older adults $[3,4]$ but middle-aged individuals are a demographic that receives less attention. The lack of information on middle-aged adults may be in part because in this cohort, sarcopenia is less prevalent, and the incidence increases dramatically in older age groups [1].
There are currently few, if any estimates on sarcopenia prevalence in Canadian middle-aged adults; however, for adults aged 65 or greater, the prevalence in males ranges from 1.4-5.2\% depending on the definition of sarcopenia used [5]. In a male Dutch cohort, the prevalence for ages 60 to 69 and over 70 were $0-31.2 \%$ and $0-45.2 \%$ respectively; thus, how frequently people have sarcopenia can be highly variable in a population, and it is potentially affecting much of the population [1]. The prevalence of sarcopenia in Europe appears to be trending upwards and is projected to increase by over $60 \%$ from 2016 to 2045 [6]. It is reasonable to assume that it will also likely increase in Canada, given our aging 
UNDERGRADUATE RESEARCH IN NATURAL AND CLINICAL SCIENCE AND TECHNOLOGY (URNCST) JOURNAL Read more URNCST Journal articles and submit your own today at: https://www.urncst.com

population [5]. Along with being prevalent, the healthcare costs associated with sarcopenia seem to be large. It has been estimated that sarcopenia accounts for $1.5 \%$ of all healthcare expenses in the United States [7].

The prevalence and costs alone make treating and preventing the development of sarcopenia, crucial health interventions but the pathologies and comorbidities further underscore the importance. Though sarcopenia is less prevalent in middle-aged adults than older adults, both experience problems such as higher chances of mortality [1], metabolic syndrome [8], osteoporosis [2], and physical injury [9]. When controlled for muscle loss that naturally comes with age, sarcopenia has also been associated with diseases like obesity, chronic kidney disease, and diabetes [10]. If sarcopenia is comorbid with obesity, the outcomes are even worse, as the two pathologies produce a synergistic effect [11].

The causes of sarcopenia and muscle loss in general are numerous, and thus, the best prevention requires a multifaceted approach [12]. There are many risk factors for sarcopenia, including age, chronic injuries, and inflammatory and hormonal disorders, which are difficult to control for [9]. However, diet has also been identified as a risk factor for sarcopenia and is one that can be assessed and modified by clinical practitioners $[9,11,12]$. One way to lower sarcopenia risk by modifying diet is to increase protein intake, especially after resistance exercise [9, 3, 11]. Dairy protein is a suitable option because it typically contains highquality protein, is cost effective, is easy to prepare, and has minimal or no side effects [9]. Of dairy products, whey protein isolate (WPI) seems to be the most effective for muscle anabolism [3]. Younger demographics typically require less ( $\geq 20 \mathrm{~g}$ ) WPI than older demographics ( $\geq 40 \mathrm{~g})$ in preventing sarcopenia [3]; however, it is unclear how middle-aged individuals may respond to WPI. This gap in the literature leaves healthcare providers to make approximations based on the range in age between young and old adults. Understanding the dosing required for the middleaged demographics may also provide insight into how middle-aged adults can reap the most rewards out of recreational resistance exercise.

Middle-aged individuals represent an important target because of the risk sarcopenia presents. Moreover, it appears that early intervention with quality protein is associated with higher muscle mass gain and when compared with low protein consumers, smaller losses of muscle mass over 3 years [13]. It has been suggested that quality dietary protein, and even more so when combined with resistance exercise for best utilization, seems to aid in maintaining muscle mass [12].

To assess the dose-response of muscle protein synthesis to WPI ingestion at rest and after resistance training in middleaged individuals, similar protocols to the ones employed by Yang et al. [3] and Wilkinson et al. [14-16] will be employed. Exercised vs. unexercised leg muscles will be assessed and varying doses of 0-40 $\mathrm{g}$ of WPI will be administered. Muscle protein synthesis (MPS) will be measured by monitoring the incorporation of the stable water isotope, $\mathrm{D}_{2} \mathrm{O}$ into muscle tissue by comparing body water deuterium enrichment to deuterium enrichment in myofibrillar protein. $\mathrm{D}_{2} \mathrm{O}$ will be used instead of injection methods employed by some studies $[3,17]$ because it has numerous benefits such as having the ability to conduct studies in a non-controlled setting, a longer half-life ( 9-11 days), the ability to label numerous substrates, and overall, it is less invasive and more cost-effective than substrate-specific tracers, supported by the work conducted by Wilkinson et al. [14]. Higher amounts of $\mathrm{D}_{2} \mathrm{O}$ will be used in this study compared to Wilkinson et al. [15] because at $0.53 \%$ of body water there was a potential for absolute FSR to be inaccurate because of decreased precision explained by Wilkinson et al. [15]. They further suggested increased dosage over a longer period to minimize the decreased precision and prevent adverse side effects. Individuals will be under BMI 30 $\mathrm{kg} / \mathrm{m}^{2}$ because of the synergistic effect that it can have with obesity [11]. We hypothesis that exercised legs and higher doses of WPI will yield the most MPS.

\section{Methods}

Participants

50 men (age $45 \pm 5$ years, BMI $<30 \mathrm{~kg} / \mathrm{m}^{2}$ ) will be recruited for the experiment. They will be counterbalanced by their age, body mass index (BMI), and physical activity levels between the groups. Then they will be randomly assigned into 1 of the 5 WPI ingestion amount cohorts (0 g, $10 \mathrm{~g}, 20 \mathrm{~g}, 30 \mathrm{~g}, 40 \mathrm{~g})$. This study will use a medical questionnaire and physical exam to exclude any participants that have metabolic, respiratory, or cardiovascular disorders $[14,15]$. After explaining the study and potential risks, all participants will give their written consent before proceeding with the experiment.

\section{Preliminary assessments}

1 week before the day of the study, the following characteristics will be obtained: age, height $(\mathrm{cm})$, total body mass $(\mathrm{kg})$, protein intake per body mass $(\mathrm{g} / \mathrm{kg})$, fat-free mass $(\mathrm{kg})$, body mass index $\left(\mathrm{kg} / \mathrm{m}^{2}\right)$, blood pressure (mmHg) [3]. Furthermore, a questionnaire will be given to assess physical activity levels. Finally, a physical performance test will be conducted to assess maximum strength by doing 10 repetitions of maximum unilateral leg extensions on their dominant leg [3].

\section{Dietary and physical activity control}

A 3-day dietary record will be obtained 5 days before the study to provide estimates of their usual macronutrient intake. Based on these dietary record responses, an average daily energy and protein intake will be determined and provided in the pre-prepared diets, 2 days before the study [3]. Using their physical activity level assessments, activity factors will be taken into account by using the HarrisBenedict equation when determining the pre-prepared diets [3]. Total body mass will be monitored during 2 days of a controlled diet to ensure they are in energy balance. 
UNDERGRADUATE RESEARCH IN NATURAL AND CLINICAL SCIENCE AND TECHNOLOGY (URNCST) JOURNAL Read more URNCST Journal articles and submit your own today at: https://www.urncst.com

Participants will also be told not to exercise 3 days before the study $[14,15]$

\section{Study protocol}

Roughly 24 hours before the study, the participants will complete the following steps at home. The individuals will first take a baseline saliva sample. Following the saliva sample, 5 doses of $150 \mathrm{~mL}$ bolus $\left(70 \% \mathrm{D}_{2} \mathrm{O}\right)$ will be consumed 2 hours apart starting at noon the day before the study. This dosing pattern will ensure that $1 \%$ body water will be labeled for the day of the study while allowing participants to selfmonitor for adverse side effects from the large consumption of $\mathrm{D}_{2} \mathrm{O}$ [14]. If participants do experience side effects, the dosing pattern will be spread out until $10 \mathrm{pm}$.

It is crucial that participants do not consume any $\mathrm{H}_{2} \mathrm{O}$ until 2 hours after the last dosage of $\mathrm{D}_{2} \mathrm{O}$, and that they consume no food past $10 \mathrm{pm}$ until 8 am the day of the study. This will ensure proper $\mathrm{D}_{2} \mathrm{O}$ equilibration, and that they are in a post-absorptive state $[16,3]$. Using an increased total dosage will be a departure from the previous work by Wilkinson et al. [14], and this will be completed to counteract measurement errors in absolute FSR (by 2-fold) due to gas chromatography- pyrolysis- isotope ratio mass spectrometer (GC-P-IRMS) decreased precision compared to the traditional primed amino acid infusion and gas chromatography-mass spectrometry (GC-MS) study design [15].

Participants will arrive at 8 am in the controlled laboratory setting on the day of the study. A saliva sample will be taken 1 hour before the exercise protocol. This will entail 10 repetitions of maximum unilateral leg extension based on their physical performance test. Following the exercise protocol, another saliva sample will be collected and then participants will consume their WPI and 45g carbohydrate mixed drink. The amount of WPI in the beverage will be based on the assigned group. The amino acid composition of WPI will be determined based on the composition from Churward-Venne et al. [17]. After the consumption of the protein and carbohydrate mixed drink, a muscle biopsy and saliva sample will be taken, representing $\mathrm{t}=0 \mathrm{~h}$. Saliva samples will be taken each hour following $\mathrm{t}=0 \mathrm{~h}$ and 2 more muscle biopsies will be taken at $\mathrm{t}=3 \mathrm{~h}$ and $\mathrm{t}=6 \mathrm{~h}$.

\section{Body water enrichment and saliva analysis}

Atom percent excess (APE) of water in the saliva will be determined using the method by Wilkinson et al. [14]. First, $100 \mathrm{uL}$ of saliva was distilled at $90^{\circ} \mathrm{C}$ for $4 \mathrm{~h}$ before transferring to vials and performing liquid injection into a high temperature conversion elemental analyzer (TC/EA). The TC/EA then feeds into an isotope ratio mass spectrometry (IRMS). Each saliva sample will be run through the TC/EA and IRMS 4 times to verify accuracy and before running the samples through TC/EA, the machine will have its validity tested in the manner outlined in Wilkinson et al. [14]. Lastly, enrichment will be calculated using equation 1 .

Zhao et al. | URNCST Journal (2021): Volume 5, Issue 4

DOI Link: https://doi.org/10.26685/urnest.231

$$
\text { Atom } \%=\frac{100 \times A R \times(\delta D \times 0.001+1)}{1+A R(\delta D \times 0.001+1)}
$$

Equation 1. Atom \% of deuterium in protein-bound alanine. AR represents the absolute ratio constant for deuterium based on the Vienna Standard Mean Ocean Water value of 0.00011595 [14]. D represents deuterium $\left({ }^{2} \mathrm{H}\right)$.

\section{Muscle biopsy sampling}

In the same manner as Yang et al. [3], a local anesthetic will be applied to both of the participant's thigh muscles and samples for biopsy will be collected via a modified Bergstrom needle [3]. The collected biopsy samples will then be purified in liquid nitrogen for storage at $-80^{\circ} \mathrm{C}[3]$.

\section{$\underline{\text { Myofibrillar protein fractions derivatization and muscle }}$ analysis}

$30-50 \mathrm{mg}$ of thawed wet muscle will be homogenized in a homogenization buffer and a protease inhibitor cocktail tablet at $10 \mu \mathrm{L} / \mu \mathrm{g}$ of tissue. The homogenates will be centrifuged and the resulting myofibrillar pellets will be solubilized with a strong base before precipitating with 1 $\mathrm{mol} / \mathrm{L}$ perchloric acid. The strong acidic slurry will then be incubated overnight at $110^{\circ} \mathrm{C}$ to release protein-bound amino acids via acid hydrolysis. Following incubation, $2 \mathrm{~mol} / \mathrm{L}$ ammonium hydroxide will be used to elute the amino acids from the slurry before evaporating until dry. The dried samples will be derivatized as their n-methoxycarbonyl methyl esters (MCME) according to the protocol of Husek and Liebich [18] with modifications from Wilkinson et al. [15]. Modifications include resuspension of the dried sample in $60 \mu \mathrm{L}$ of distilled water and $32 \mu \mathrm{L}$ methanol, then $10 \mu \mathrm{L}$ pyridine and $8 \mu \mathrm{L}$ methylchloroformate after a brief vortex [15]. Once incorporated, an additional $30 \mathrm{~s}$ vortex will be performed followed by extraction with $100 \mu \mathrm{L}$ chloroform [15]. Then the amount of incorporated deuterium in proteinbound alanine will be determined using the GC-P-IRMS protocol outlined by Wilkinson et al. [15]. The atom $\%$ will then be determined using equation 1. After determining deuterium atom $\%$, atom percent excess (APE) will be determined by correcting for the baseline saliva sample.

\section{Calculations of fractional synthetic rate (FSR)}

The fractional synthetic rate (FSR) of myofibrillar proteins using the $\mathrm{D}_{2} \mathrm{O}$ tracer will be determined using the precursor product approach from the incorporation of deuterium-labeled alanine into protein using enrichment of body water [19]. 
UNDERGRADUATE RESEARCH IN NATURAL AND CLINICAL SCIENCE AND TECHNOLOGY (URNCST) JOURNAL Read more URNCST Journal articles and submit your own today at: https://www.urncst.com

$$
\operatorname{FSR}(\% / h)=\frac{[\text { APEAla }]}{[n \times \text { APEp } \times t]} \times 100 \%
$$

Equation 2. FSR of the myofibrillar proteins as calculated using APE of precursor and alanine. $\mathrm{APE}_{\mathrm{Ala}}$ is the deuterium enrichment of protein-bound alanine which will be determined during the muscle analysis of both exercised and unexercised leg biopsies. $\mathrm{APE}_{\mathrm{P}}$ is the mean precursor enrichment over the time of 6 hours which will be determined during saliva analysis. $t$ is the time between biopsies meaning calculations will be made at each muscle biopsy for each leg. $\mathrm{n}$ is the exchange constant (3.7) of deuterium ( $\mathrm{D}$ or ${ }^{2} \mathrm{H}$ ) between body water in mammals [19].

For each WPI ingestion amount, the FSR percentages will be calculated every hour from the participant's exercised and unexercised leg. The values at each time point will be used to determine the average FSR for exercised and unexercised leg separately.

\section{Statistical Analysis}

Consistent with Yang et al. [3], an analysis of variance (ANOVA) test will be performed at each WPI dose to determine the statistical significance $(\mathrm{P}<0.05)$ between FSR $(\% / \mathrm{h})$ in the exercised and unexercised legs. In accordance with Churchward-Venne et al. [17], the causal relationship between protein ingestion ( $\mathrm{g}$ protein per kg body mass) and FSR $(\% / \mathrm{h})$ will be assessed by linear regression $(\mathrm{P}<0.05)$ for both the exercised leg and for unexercised leg conditions. The data from the 5 ANOVA tests and the 2 linear regressions will be presented as mean FSR $(\% / \mathrm{h})+/$ standard error of the mean (SEM).

SPSS for Windows will be used to perform all the statistical analysis.

\section{Discussion}

We anticipate there will be a bi-phasic curve in both of our linear regressions with a positive slope at low $\mathrm{g} / \mathrm{kg}$ and plateau at higher $\mathrm{g} / \mathrm{kg}$ values. Given that body mass will be unknown before recruiting the participants, the exact point of plateau in $\mathrm{g} / \mathrm{kg}$ will be unknown; however, we expect the plateau for the unexercised leg to correspond with $\sim 20 \mathrm{~g}$ WPI $[3,20]$. For the exercised leg, we expect it to plateau at $\sim 30 \mathrm{~g}$ WPI [3, 17, 21, 22]. Our reasoning for those bi-phasic curves is as follows: after said points, increased dosage of WPI ingestion will lead to the same amount of FSR $(\% / \mathrm{h})$. Furthermore, we anticipate that there will be a significant increase in FSR $(\% / \mathrm{h})$ when comparing unexercised versus exercised legs at each WPI ingestion amount [3].

$40 \mathrm{~g}$ of WPI will be used as the upper limit dose, as $40 \mathrm{~g}$ appears to be the upper limit for optimal myofibrillar protein synthesis (MPS) [17]. If the results were to fall within the 20-40 g range during rest and after resistance exercise, this would also lend support to current research suggesting that response to WPI decreases with increasing age [3, 4, 12] If there exists an optimal dose of WPI for MPS at rest and after resistance training, this will support that in addition to younger and older adults [3, 4], middle-aged adults also experience protein dose-dependent effects when synergistically combined with resistance exercises.

Although there are many strengths to our method, there are also inherent limitations. Firstly, due to the greater number of participants compared to some previous studies $[14,15]$, type II errors will not be expected in our data; however, there is a greater likelihood this will result in decreased adherence to the protocol due to high study demands [23], which could potentially impact findings. Secondly, recruiting only men in our study decreases sexbased differences that are coupled with increased age as confounding variables [24-26] but this lowers external validity in treating the broader population. Furthermore, studies that laid the foundation for this protocol $[3,4,14,15$, $17,20]$ characteristically underrepresent women and thus, the sex-based implications remain largely unknown. Lastly, there are some drawbacks to using $\mathrm{D}_{2} \mathrm{O} . \mathrm{D}_{2} \mathrm{O}$ is a valid and reliable technique for measuring FSR $(\% / \mathrm{h})$, moreover, it is cheaper and less invasive compared to the traditional injection of stable isotope tracers. However, ensuring the correct dosage of a single $\mathrm{D}_{2} \mathrm{O}$ bolus to balance its adverse effects, its decreased analytical precision, and decreasing measurement error to account for the precision difficulties, may be challenging [15].

All in all, it is beneficial for physicians to know the optimal dose for MPS in middle-aged adults so they may provide more accurate recommendations of proactive protein intake. Given that current studies assessing MPS in younger and older adults have a range of 20-40g of WPI, there is a great deal of guesswork involved for middle-aged adults. Determining the optimal dose for MPS in middle-aged adults will, therefore, ensure physicians are better equipped to prevent sarcopenia in their patients.

\section{Conclusions}

Sarcopenia is highly prevalent $[1,5,6]$, taxing on healthcare, economy $[1,7]$, and is associated or comorbid with diseases that can negatively impact life or even increase fatality [1, 2, 8-11]. With these concerns in mind, healthcare professionals must take note of risk factors and begin proactive measures with patients. By assessing how middleaged men respond to exercise and WPI ingestion, better recommendations can be made for patients at risk for sarcopenia.

\section{List of Abbreviations Used}

WPI: whey protein isolate $\mathrm{D}_{2} \mathrm{O}$ : deuterium oxide (heavy water)

BMI: body mass index

AR: absolute ratio

ANOVA: analysis of variance

SEM: standard error of mean

APE: atom percent excess

FSR: fractional synthetic rate 
UNDERGRADUATE RESEARCH IN NATURAL AND CLINICAL SCIENCE AND TECHNOLOGY (URNCST) JOURNAL Read more URNCST Journal articles and submit your own today at: https://www.urncst.com

MPS: myofibrillar protein synthesis

GC-P-IRMS: gas chromatography-pyrolysis-isotope ratio mass spectrometry

GC-MS: gas chromatography-mass spectrometry

TC/EA: temperature conversion elemental analysis

IRMS: isotope ratio mass spectrometry

MCME: n-methoxycarbonyl methyl esters

\section{Conflicts of Interest}

The authors declare that they have no conflict of interests.

\section{Ethics Approval and/or Participant Consent}

This research protocol did not require any ethics approval or participant consent as no experiment was conducted, nor any live participants recruited. If this study were carried out, further ethics approval and participant consent would be obtained from appropriate ethics boards, committees, and/or organizations.

\section{Authors' Contributions}

All authors contributed equally to writing, editing and finalizing the manuscript.

\section{Acknowledgements}

The authors want to thank Alexandra D. Goudreau for proofreading this manuscript.

\section{Funding}

This study was not funded.

\section{References}

[1] Santilli V, Bernetti A, Mangone M, Paoloni M. Clinical definition of sarcopenia. Clin Cases Miner Bone Metab. 2014 Sep;11(3):177-80.

[2] Bijlsma AY, Meskers CGM, Ling CHY, Narici M, Kurrie SE, Cameron LD et al. Defining Sarcopenia: The Impact of Different Diagnostic Criteria on the Prevalence of Sarcopenia in a Large Middle Aged Cohort. Nutrients. 2013Feb;33:871-881. https://doi.org/10.1007/s11357-012-9384-Z

[3] Yang Y, Breen L, Burd NA, Hector AJ, ChurchwardVenne TA, Josse AR, Tarnopolsky MA, Phillips SM. Resistance exercise enhances myofibrillar protein synthesis with graded intakes of whey protein in older men. Br J Nutr. 2012 Nov 28;108(10):1780-8. https://doi.org/10.1017/s0007114511007422

[4] Moore DR, Churchward-Venne TA, Witard O, et al. Protein ingestion to stimulate myofibrillar protein synthesis requires greater relative protein intakes in healthy older versus younger men. The Journals of gerontology. Series A, Biological Sciences and Medical Sciences. 2015 Jan;70(1):57-62. https://doi.org/10.1093/gerona/glu103 DOI: 10.1093/gerona/glu103.
[5] Purcell SA, MacKenzie M, Barbosa-Silva TG, Dionne IJ, Ghosh S, Olobatuyi OV, Siervo M, Ye M, Prado CM. Sarcopenia Prevalence Using Different Definitions in Older Community-Dwelling Canadians. J Nutr Health Aging. 2020;24(7):783-790. https://doi.org/10.1007/s12603-020-1427-Z

[6] Ethgen O, Beaudart C, Buckinx F, Bruyère O, Reginster JY. The Future Prevalence of Sarcopenia in Europe: A Claim for Public Health Action. Calcif Tissue Int. 2017 Mar;100(3):229-234. https://doi.org/10.1007/s00223016-0220-9

[7] Janssen I, Shepard DS, Katzmarzyk PT, Roubenoff R. The healthcare costs of sarcopenia in the United States. J Am Geriatr Soc. 2004 Jan;52(1):80-5 https://doi.org/10.1111/j.1532-5415.2004.52014.X

[8] Zhang H, Lin S, Gao T, Zhong F, Cai J, Sun Y, Ma A. Association between Sarcopenia and Metabolic Syndrome in Middle-Aged and Older Non-Obese Adults: A Systematic Review and Meta-Analysis. Nutrients. $2018 \quad$ Mar 16;10(3):364. https://doi.org/10.3390/nu10030364

[9] Hanach NI, McCullough F, Avery A. The Impact of Dairy Protein Intake on Muscle Mass, Muscle Strength, and Physical Performance in Middle-Aged to Older Adults with or without Existing Sarcopenia: A Systematic Review and Meta-Analysis. Adv Nutr. 2019 Jan 1;10(1):59-69. https://doi.org/10.1093/advances/nmy065

[10] Beaudart C, Rizzoli R, Bruyère O, Reginster JY, Biver E. Sarcopenia: burden and challenges for public health. Arch Public Health. 2014 Dec 18;72(1):45. https://doi.org/10.1186/2049-3258-72-45

[11] Batsis JA, Villareal DT. Sarcopenic obesity in older adults: aetiology, epidemiology and treatment strategies. Nat Rev Endocrinol. 2018 Sep;14(9):513537. https://doi.org/10.1038/s41574-018-0062-9

[12] Burd NA, Mckenna CF, Salvador AF, Paulussen KJM, Moore DR. Dietary Protein Quantity, Quality, and Exercise Are Key to Healthy Living: A Muscle-Centric Perspective Across the Lifespan. Frontiers in Nutrition. Frontiers in Nutrition; 2019;6. https://doi.org/10.3389/fnut.2019.00083

[13] Houston DK, Nicklas BJ, Ding J, Harris TB, Tylavsky FA, Newman AB, Lee JS, Sahyoun NR, Visser M, Kritchevsky SB; Health ABC Study. Dietary protein intake is associated with lean mass change in older, community-dwelling adults: the Health, Aging, and Body Composition (Health ABC) Study. Am J Clin Nutr. $2008 \quad$ Jan;87(1):150-5. https://doi.org/10.1093/ajcn/87.1.150

[14] Wilkinson DJ, Cegielski J, Phillips BE, Boereboom C, Lund JN, Atherton PJ, Smith K. Internal comparison between deuterium oxide (D2O) and L-[ring-13C6] phenylalanine for acute measurement of muscle protein synthesis in humans. Physiol Rep. 2015 Jul;3(7):e12433. https://doi.org/10.14814/phy2.12433 
UNDERGRADUATE RESEARCH IN NATURAL AND CLINICAL SCIENCE AND TECHNOLOGY (URNCST) JOURNAL

Read more URNCST Journal articles and submit your own today at: https://www.urncst.com

[15] Wilkinson DJ, Franchi MV, Brook MS, Narici MV, Williams JP, Mitchell WK, Szewczyk NJ, Greenhaff PL, Atherton PJ, Smith K. A validation of the application of $\mathrm{D}_{2} \mathrm{O}$ stable isotope tracer techniques for monitoring day-to-day changes in muscle protein subfraction synthesis in humans. Am J Physiol Endocrinol Metab. 2014 Mar 1;306(5):E571-9. https://doi.org/10.1152/ajpendo.00650.2013

[16] Wilkinson DJ, Brook MS, Smith K, Atherton PJ. Stable isotope tracers and exercise physiology: past, present and future. J Physiol. 2017 May 1;595(9):2873-2882. https://doi.org/10.1113/JP272277

[17] Churchward-Venne TA, Pinckaers PJM, Smeets JSJ, Betz MW, Senden JM, Goessens JPB, Gijsen AP, Rollo I, Verdijk LB, van Loon LJC. Dose-response effects of dietary protein on muscle protein synthesis during recovery from endurance exercise in young men: a double-blind randomized trial. Am J Clin Nutr. 2020 Aug https://doi.org/10.1093/ajen/nqaa073

[18] Husek P, Liebich HM. Organic acid profiling by direct treatment of deproteinized plasma with ethyl chloroformate. J Chromatogr B Biomed Appl. 1994 Jun 3;656(1):37-43. https://doi.org/10.1016/03784347(94)00089-1

[19] Gasier HG, Fluckey JD, Previs SF. The application of ${ }^{2} \mathrm{H}_{2} \mathrm{O}$ to measure skeletal muscle protein synthesis. Nutr Metab (Lond). $2010 \quad$ Apr 21;7:31. https://doi.org/10.1186/1743-7075-7-31

[20] Witard OC, Jackman SR, Breen L, Smith K, Selby A, Tipton KD. Myofibrillar muscle protein synthesis rates subsequent to a meal in response to increasing doses of whey protein at rest and after resistance exercise. Am J Clin Nutr. $2014 \quad$ Jan;99(1):86-95. https://doi.org/10.3945/ajen.112.055517
[21] Trommelen J, Betz MW, van Loon LJC. The Muscle Protein Synthetic Response to Meal Ingestion Following Resistance-Type Exercise. Sports Med. 2019 Feb;49(2):185-197. $\quad$ https://doi.org/10.1007/s40279019-01053-5

[22] Macnaughton LS, Wardle SL, Witard OC, McGlory C, Hamilton DL, Jeromson S, Lawrence CE, Wallis GA, Tipton KD. The response of muscle protein synthesis following whole-body resistance exercise is greater following $40 \mathrm{~g}$ than $20 \mathrm{~g}$ of ingested whey protein. Physiol Rep. $2016 \quad$ Aug;4(15):e12893. https://doi.org/10.14814/phy2.12893

[23]Zweben A, Fucito LM, O'Malley SS. Effective Strategies for Maintaining Research Participation in Clinical Trials. Drug Inf J. 2009 Jul;43(4):10.1177/009286150904300411.

https://doi.org/10.1177\%2F009286150904300411

[24] Scalzo RL, Peltonen GL, Binns SE, Shankaran M, Giordano GR, Hartley DA, Klochak AL, Lonac MC, Paris HL, Szallar SE, Wood LM, Peelor FF 3rd, Holmes WE, Hellerstein MK, Bell C, Hamilton KL, Miller BF. Greater muscle protein synthesis and mitochondrial biogenesis in males compared with females during sprint interval training. FASEB J. 2014 Jun;28(6):270514. https://doi.org/10.1096/fj.13-246595

[25] Markofski MM, Volpi E. Protein metabolism in women and men: similarities and disparities. Curr Opin Clin Nutr Metab Care. 2011 Jan;14(1):93-7. https://doi.org/10.1097/MCO.0b013e3283412343

[26] Smith GI, Mittendorfer B. Sexual dimorphism in skeletal muscle protein turnover. J Appl Physiol (1985). 2016 Mar 15;120(6):674-82. https://doi.org/10.1152/japplphysiol.00625.2015

\section{Article Information}

Managing Editor: Jeremy Y. Ng

Peer Reviewers: Sera Whitelaw

Article Dates: Received Jan 06 21; Accepted Feb 06 21; Published Apr 0621

\section{Citation}

Please cite this article as follows:

Zhao D, Evers P. Effects of whey protein isolate ingestion on muscle protein synthesis at rest and after resistance-exercise in middle-aged men: A research protocol. URNCST Journal. 2021 Apr 06: 5(3).

https://urncst.com/index.php/urncst/article/view/231

DOI Link: https://doi.org/10.26685/urncst.231

\section{Copyright}

(C) David Zhao, Parrish Evers. (2021). Published first in the Undergraduate Research in Natural and Clinical Science and Technology (URNCST) Journal. This is an open access article distributed under the terms of the Creative Commons Attribution License (https://creativecommons.org/licenses/by/4.0/), which permits unrestricted use, distribution, and reproduction in any medium, provided the original work, first published in the Undergraduate Research in Natural and Clinical Science and Technology (URNCST) Journal, is properly cited. The complete bibliographic information, a link to the original publication on http://www.urncst.com, as well as this copyright and license information must be included. 

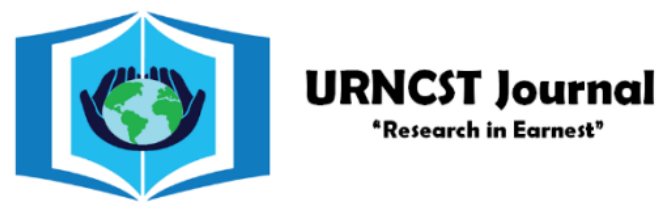

\section{Funded by the Government of Canada}

\section{Canadằ}

Do you research in earnest? Submit your next undergraduate research article to the URNCST Journal!

| Open Access | Peer-Reviewed | Rapid Turnaround Time | International | | Broad and Multidisciplinary | Indexed | Innovative | Social Media Promoted |

Pre-submission inquiries? Send us an email at info@urncst.com | Facebook, Twitter and LinkedIn: @URNCST Submit YOUR manuscript today at https://www.urncst.com! 